\title{
Analysis of Opinion Text "Challenges of the Simultaneous Regional Election" (Fowler Critical Review)
}

\author{
Izhar $^{*}$, Seftika $^{2}$ \\ Student of Postgraduate Program in Language Education Science,State University of \\ Semarang, Semarang, Indonesia ${ }^{1}$ \\ Student of Postgraduate Program in Language Education Science,State University of \\ Semarang, Semarang, Indonesia ${ }^{2}$ \\ \{izharhamka@gmail.com¹ $\}$
}

\begin{abstract}
The topic of regional head elections in the mass media is interesting to be studied. The mass media often brings a certain influence and ideology to the voting community by marginalizing events leading up to the election contestation. This study aims to analyze the use of vocabulary and grammar in the opinion text "Challenges of the Simultaneous Regional Elections" published online by Jawaposcom on December 14, 2019 with a critical discourse study by Roger Fowler. The method used in this researcher is descriptive qualitative method. The results showed that vocabulary used in the form of: (1) vocabulary to classify, namely: challenge and all-out, (2) vocabulary of discourse fighting, namely: challenge figures and campaign patterns, (3) vocabulary limiting views, namely: no less interesting, moreover, in large part, and its meaning, (4) the vocabulary of marginalization: fraud and pragmatic interests. Then, in the use of grammar, the sentences were found to tend to (1) be active to represent the challenges in the 2020 simultaneous regional elections and (2) the subject nominalization to scrutinize media opinion.
\end{abstract}

Keywords: Critical Discourse Analysis; grammar; opinion and vocabulary

\section{Introduction}

From many information presented in mass media, regional head elections (Pilkada) is one of the hot news that many elements talk about Indonesian people from remote villages to the middle of the city. Election regional heads discourse is a trending topic that has attracted a lot of public attention. Because, it is not only the ideals of development and welfare that are being discussed by society, but also political packaging assumption by marginalizing figures and the atmosphere that colored the contestation made the news warmer. No wonder, the political paradigm and logic of the Pilkada was raised to answer public curiosity and provide stigma regarding the sustainability of the elections.

One of the online mass media that provides information about the choice of district head is 
the online Jawa Pos mass media. The mass media is one mass media which quite a lot of public attention. It can be seen from the content, rubrics, and quality of the changes. Setyawan (2014: 709) stated that among the existed digitals media, Jawa Pos has made various quality improvements, starting from the substance of the content, changes, and various rubrics. Additionally, Lenggawa (2019: 37) stated that in facing the business competition and threats inindustrial era 4.0, Java post has built a network pattern that can connect media, online business, and communications infrastructure. That is why, it seems that the Jawa Pos mass media is a media that deserves to be taken into account in the news or various opinions, including the discourse on the 2020 regional head election, which was published approximately one year ago, namely December 14,2019 . In

Basically, when people observe carefully, the discourse of the news is not just made to just provide information but also contain the author's ideology, even ideology of institutions. Critical readers will find this ideology in language or linguistics used by the author in conveying a thought. The language is packaged in a choice of vocabulary and sentences. Moreover, nowadays the mass media can freely reveal a related matter with social phenomena and power. The media dare to reveal things that are felt lame with straight forward words, not using euphemism or metaphor. Some authors use sentences directly to show a subject or phenomenon and some others hide a number of subjects or phenomena by design passive sentence. So, it can be said that language is a key that influence perception and critical linguistics are used to analyze the phenomenon of gap through what is represented through language. Furthermore, written editors can be neutral, biased, and even misleading (Montejo \& Adriano, 2018: 70).

Therefore, the existence of critical linguistics in mass media discourse has a role in interpreting, uncovering hidden implicit things in information, and also to discover hidden ideologies. As stated by Fowler in Anang Santoso (2008), Critical linguistics has a role in discovering ideologies that are not written down direct and know ideology specifically in the context of social formation. In fact, the language style is also considered capable of forming a public conceptualization of the coverage of certain groups (Catalano \& Wough, 2013: 406). So, even in analyzing, sometimes it is necessary to review the meaning outside the context (Thompson in Olusanya, 2013: 178). In essence, through language (vocabulary and sentences) Fowler wanted to know writer's ideology that appears in a resulted discourse.

Therefore, this study tried to describe the opinion discourse "Challenges of the simultaneous regional election in 2020" of Jawa Pos online mass media based on the language usage, namely Roger Fowler's vocabulary and sentences.

\section{Method}

This study used a qualitative research which carefully describes the language information contained in the text "Challenges of the simultaneous Regional Election in 2020". Moleong (2007: 11) suggests that descriptive research emphasizes data in the form of words, pictures, and not numbers caused by the application of qualitative methods. Then, Sugiyono (2010: 15) also explains that qualitative research is research based on the philosophy of positivism, used to research under natural conditions. This condition is a natural condition that is not engineered at all in order to achieve the objectives of the activity. The data source of this research is the opinion text " Challenges of the simultaneous Regional Election in 2020" which was published online by Jawaposcom on December 14, 2019. The data in the study were vocabulary quotes and sentences represented containing certain ideologies. Data was collected through the document study method, namely the collection method that examines 
the document as material for its study. Then, the data were analyzed using Roger Fowler's discourse analysis model, namely language analysis in terms of vocabulary and sentences. In the term of vocabulary, the assessment includes (a) able to classify certain realities in categorization and finally differentiated with other realities, (b) able to limit views, (c) become the realm in the discourse struggle, and (d) become a means of marginalization. Then, in terms of sentences, the assessment is viewed from the identification of active sentences or passive sentences and subject nominalization. The steps taken in data analysis are: (a) intensive reading of the text, (b) identifying and clarifying, (c) analyzing the text critically, and (d) presenting the results of the analysis. The analysis results are presented comprehensively in descriptive form.

\section{Results and Discussion}

The focus of Roger Fowler's attention as quoted by Ghassani (2018) is the use of the language of social practice which carries certain implications and ideologies. It means that analysis refers to representational language. It is about the way groups, a certain person, activity, or event is displayed in public discourse. Through those, the ideology of the media will appear.

Based on the study, it was found that there was a use of vocabulary in the form of: (1) vocabulary makes classifications, such as: tantangan and habis-habisan, (2) vocabulary of discourse fight, such as: tantangan figure and pola kampanye, (3) vocabulary limits views, such as: tak kalah menarik, apalagi, sebagian besar, (4) vocabulary marginalization, such as: : kecurangan and kepentingan pragmatis. Then, in the use of grammar, the sentences were found to tend to (1) be active to represent the challenges in the 2020 simultaneous regional elections and (2) the subject nominalization to scrutinize media opinion.

From each paragraph topic in the text, the conclusion is that the dominant topic in the opinion "Challenges of the simultaneous regional election" is that the simultaneous regional head elections in 2020. It will experience various challenges for regional head candidates, in the form of political dynamics, figures, voters, and campaigns. . In this discourse, it can be seen that there is a strategy to use vocabulary and sentences in the information conveyed. In terms of ideology, it appears that the author supports or expects the establishment of values based on the system that has been formed. It can be seen that there is an assumption of marginalizing a number of behavioral elements in a number of regional elections.

Vocabulary: makes classifications vocabulary

In the opinion entitled challenges of 'simultaneous regional election', there is an all-out and challenging in which if it is observed, it will give certain classifications in terms of importance. When it is interpreted, the word "tantangan" means "upaya yang menggugah" which is not only for a certain group of people or parties, but also aimed at all elements. In addition, the word "habis-habisan" means " habis sama sekali atau tidak ada sisa sama sekali". The vocabulary can be interpreted that in the implementation of regional election later, all those who have an interest in being hyped will fight seriously to win the contest. They mobilized various efforts and strengths, both by cadres, parties, sympathizers, and capital owners.

Vocabulary: Limiting Views

Vocabulary also has an effect on one's thoughts and assumptions about what is being informed. Because, once the vocabulary is identified, the reader will immediately associate it 
with the realities that occur in their lives. The diction used by the media can limit our view of something. In other words, with an interesting news style and use of diction, readers are limited to further understanding the positive things that are being reported or readers are limited to further understanding into the negative realm. The diction in the opinion, such as: tak kalah menarik, apalagi, sebagian besar, dan artinya. These vocabularies emphasize the author's opinion which makes the reader more confident and limits the reader's paradigm which is contrary to the author's opinion.

Vocabulary: Discourse fight

The use of vocabulary also essentially describes the discourse battle between parties who have an interest in the discourse of the 2020 simultaneous regional election challenges above. Discourse fight in the above opinion can be categorized as discourse battles by the media / writers who take part in reporting. Either as a role taker who takes the most or least reporting positions, or as a role taker. This is because each media has its own version in response to an event. In fact, not only that, the media wants its version to be more justified and more determinative of public opinion. The vocabulary of discourse fighting that is described in the above opinion such as: figure challenges and campaign patterns ( tantangan figur and pola kampanye). In this case, it is clear that the opinion regarding the challenge of the figure and the campaign pattern provides space for discourse battle between the writer and the reader as the interpreter, maybe even as a figure who takes part directly in the world of politics.

The vocabulary of marginalization

Even though it is written in soft language, the term marginalization still has a bad impression if it is fully expressed. This can be seen in the vocabulary used by the media in the opinion, namely the vocabulary of fraud and pragmatic interests. The vocabulary seems to give the reader a stigma that in every regional election there will always appear various forms of cheating and pragmatic interests between stakeholders, especially those in power.

Furthermore, the sentences used in reporting can be in the form of active sentences or passive sentences or both. Each of these sentences is used with different emphasis. In the active sentence, the emphasis is on the subject of the actor. Meanwhile, in the passive sentence the emphasis is on the object. So, if it is converted into a passive sentence, then (the subject in the active sentence which becomes the object in the passive voice) can be hidden or removed. Several active sentences contained in the text reveal the characteristics or typical of regional head elections wherever they are in Indonesia, for example:

" Di sisi lain, lantaran jumlahnya banyak, partai akan berjuang habis-habisan untuk bisa

meraih kemenangan sebesar-besarnya di setiap daerah" (par. 3).

Furthermore, the nominalization or elimination of a number of objects appears in the sentence:

"ada sejumlah tantangan yang menarik untuk dicermati terkait gelaran pilkada serentak 2020 " (par. 2).

In the sentence, it appears that the subject referred to by the author is missing or does not show. This is because the authors did not present any actors to examine the challenges in the regional elections.

\section{Conclusion}

Based on this study, it is known that the use of vocabulary and sentence in the opinion text "Challenges of simultaneous regional elections in 2020" in the mass media online Jawa Pos 
focuses on the characteristics of the election event itself.

\section{References}

[1] Ali Rif'an. (2019).tantangan pilkada serentak 2020 (opini). Jawaposcom. 14 Desember 2019. Accesed on 9 April 2020 pukul 09.52 WIB.

[2] Catalano, Theresa \& Waugh, Linda R. (2013). The ideologies behind newspaper crime reports of Latinos and Wall Street/CEOs: a critical analysis of metonymy in text and image, Critical Discourse Studies, 10 (4), 406-426, DOI: 10.1080/17405904.2013.813774

[3] Ghassani, Mega Amalia. (2018). Wacana berita kriminal koran Jawa pos: Analisis wacana kritis Roger Fowler. Skripsi, Universitas Airlangga.

[4] Lenggawa, Veza Aditya. (2019). Strategi jawa pos dalam menghadapi persaingan bisnis media di era revolusi industri 4.0. Jurnal Konvergensi, 01(01), 19-38.

[5] Moleong, Lexy J. (2007). Metodologi penelitian kualitatif. Bandung. Remaja Rosda Karya.

[6] Montejo, Glorilyn M. \& Adriano, Teresita Q. (2018). A critical discourse analysis of headlines in onlinenews portals. Journal of Advances in Humanities and Social Sciences. 4 (2), 70-83, DOI: 10.20474/jahss-4.2.2.

[7] Olusanya, Ayoola Moses. (2013). An interpersonal metafunction analysis of some selected political advertisements in some Nigerian newspapers. International Journal of Humanities and Social Science. 3 (8) [Special Issue - April 2013], 165-178.

[8] Setyawan, Irwan. (2013). Media cetak bertahan hidup (strategi jawa pos indonesia dan the straits times Singapura mempertahankan eksistensinya dari gempuran media online). Prosiding seminar besar komunikasi@2014, Padang: 25 - 27 November 2013, 702-711.

[9] Sugiyono. (2010). Metode Penelitian Pendidikan: Pendekatan Kualitatif dan Kuantitatif. Bandung: Alfabeta.

[10] Susanto, Anang. (2008). Jejak Halliday dalam lingustik kritis. Jurnal Bahasa dan Seni, No. 36 Vol. 1, 1-15. 